\title{
Probing Differences in Mass-Transfer Coefficients in Beaker and Stirrer Digestion Systems and the USP Dissolution Apparatus 2 Using Benzoic Acid Tablets
}

\author{
Timothy A. G. Langrish * , Chao Zhong $\mathbb{D}$ and Lizhe Sun \\ Drying and Process Technology Research Group, School of Chemical and Biomolecular Engineering, \\ The University of Sydney, Camperdown, NSW 2006, Australia; czho7722@uni.sydney.edu.au (C.Z.); \\ lsun5886@uni.sydney.edu.au (L.S.) \\ * Correspondence: timothy.langrish@sydney.edu.au
}

check for updates

Citation: Langrish, T.A.G.; Zhong, C.; Sun, L. Probing Differences in Mass-Transfer Coefficients in Beaker and Stirrer Digestion Systems and the USP Dissolution Apparatus 2 Using Benzoic Acid Tablets. Processes 2021, 9, 2168. https://doi.org/10.3390/ pr9122168

Academic Editors: Yoshimichi

Hagiwara, Tomonori Waku and Satoshi Ogata

Received: 8 November 2021

Accepted: 29 November 2021

Published: 2 December 2021

Publisher's Note: MDPI stays neutral with regard to jurisdictional claims in published maps and institutional affiliations.

Copyright: (C) 2021 by the authors. Licensee MDPI, Basel, Switzerland. This article is an open access article distributed under the terms and conditions of the Creative Commons Attribution (CC BY) license (https:/ / creativecommons.org/licenses/by/ $4.0 /)$.

\begin{abstract}
Measurements of external mass-transfer coefficients for dissolution have been made with benzoic acid tablets with a diameter of $13 \mathrm{~mm}$ and approximately $3 \mathrm{~mm}$ thick, using two different dissolution systems. One system has been a beaker with a platform for the tablet and either $80 \mathrm{~mL}$ or $120 \mathrm{~mL}$ of water, with three different types of stirrers, and the other has been a USP dissolution apparatus 2 (paddle) with either $200 \mathrm{~mL}$ or $900 \mathrm{~mL}$ water. Various stirring speeds have also been used in the different pieces of equipment. The same mass-transfer coefficient may potentially be obtained from the same tablet by adjusting the operating conditions in the two different devices. The ranges of the external mass-transfer coefficients measured in both devices overlapped significantly, with the range being $0.193-4.48 \times 10^{-5} \mathrm{~m} \mathrm{~s}^{-1}$ in the beaker and stirrer system and $0.222-3.45 \times 10^{-5} \mathrm{~m} \mathrm{~s}^{-1}$ in the USP dissolution apparatus 2. Dimensional analysis of the results, using Sherwood and Reynolds numbers, shows that the Ranz-Marshall correlation provides a lower bound for estimates of the Sherwood numbers measured experimentally. Calculations of time constants for mass transfer suggest that mass transfer may be a rate-limiting step for dissolution and food digestion under some circumstances. The range of mass-transfer coefficients measured here is representative of other measurements from the literature, and the use of the Ranz-Marshall correlation supports the suggestion that this range of values should be generally expected in most situations.
\end{abstract}

Keywords: mass transfer; dimensional analysis; time constants

\section{Introduction}

The qualitative links between mass transfer theory and human digestion have been understood for a long time. For example, Cussler [1] on Page 75, Example 3.5-2, discusses a dissolving pill, and peristaltic flow in the gut, on Page 76, for example, stating "There is certainly peristaltic flow in the gut that sharply increases mass transfer." The qualitative links and connections between digestion, mass transfer theory and momentum transfer, fluid mechanics, rheology, materials engineering and stress-strain analysis are clear from this monograph [1]. However, the quantitative understanding of the links between mass transfer theory and human digestion has not been explored in any detail, and Cussler [1] does not do any quantitative calculations for these links.

From basic mass-transfer theory, as part of the overall area of transport phenomena, the mass-transfer rate $(N)$ for a component $(A)$ from a solid (e.g., food) to a liquid (e.g., solution) may be defined by the following Equations [1,2]:

$$
N_{A}=K A\left(C_{s}-C_{b}\right)
$$

where $K$ is the overall mass-transfer coefficient, $A$ is the interfacial area (between the two phases) for mass transfer, $C_{S}$ is the saturation concentration of the solute (just outside 
the solid, above the solid surface), and $C_{b}$ is the bulk concentration of the solute in the solution. The saturation concentration for a solute in a solvent is usually a function of the solution temperature.

Equation (1), while simple, is also quite powerful, because it separates physical considerations from chemical ones. Physical considerations include the geometry, the flow rate, and other operating conditions, all of which mainly affect the mass-transfer coefficient. Chemical considerations include the concentration driving force (which is a strong function of the saturation concentration of the solute in the solvent), the individual nature of the solute (its association with the solid and other solutes), other solutes in the solution, the solvent, and the temperature, amongst other variables.

The mass-transfer coefficient may be estimated using Equation (1) and concentration measurements as a function of time with unsteady-state mass balances, as will be demonstrated later, with the choices of a suitable solute-solvent system. The choices of solute and solution are important. Cussler [1] suggests the use of benzoic acid as a solute in water as a solvent for the measurement of mass-transfer coefficients in solid-liquid systems, since the advantages of this solute-solvent combination include the following aspects:

1. Easy measurement, including titration with a base or UV spectrophotometry.

2. The external mass-transfer coefficient is clearly measured, with simple solid-fluid dissolution, and there are no reaction or dissociation effects of the solute in solution, such as in the case of aspirin.

3. There is a clear solid-liquid interface, giving a clear and well-defined surface area for the dissolution of the solute (benzoic acid).

There are a few examples for the use of this solute-solvent combination (benzoic acid-water) in the literature for measuring mass-transfer behaviour in these dissolution systems. In addition, the technique is well established in the literature for measurements of mass-transfer coefficients in other liquid-solid systems (with several systems, for example; for fractional extraction, by Irandoust and Andresson [3] and Chan et al. [4]; for gallstone dissolution, by Ding and Cussler [5] and Tao et al. [6]; and for photoresist dissolution, by Hunek and Cussler [7]). D'Arcy et al. [8] used benzoic acid tablets to study the USP dissolution apparatus 2 (paddle) experimentally and numerically, but they only measured mass-transfer rates, not the mass-transfer coefficients that are more fundamental parameters. As Equation (1) shows, the mass-transfer rate varies (implicitly) with the temperature, even with the same mass-transfer coefficient in the same equipment, since the saturation concentration $\left(C_{s}\right)$ depends on the temperature. D'Arcy et al. [9] studied the USP dissolution apparatus 1 (basket) experimentally, using benzoic acid and salicylic acid tablets to determine the dissolution rates, but the corresponding mass-transfer coefficients were not calculated or compared with other types of dissolution apparatus. Separately, D'Arcy et al. [10] studied the USP dissolution apparatus 4 (flow through cell) with a computational fluid dynamics study, assuming laminar, time-dependent flow, and did an experimental study using benzoic acid and salicylic acid tablets to determine the dissolution rates. No shear stresses or shear strain rates were estimated or measured, and the mass-transfer coefficients were also not calculated. Once again, the results were not compared with other types of apparatus. Other measurements of mass-transfer coefficients in the literature include the measurements of Tharakan et al. [11] in their in-vitro simulated model of a small intestine (0.5-3.4 $\left.\times 10^{-6} \mathrm{~m} \mathrm{~s}^{-1}\right)$, and Bai and Armenante [12], who measured mass-transfer coefficients for salicylic acid tablet dissolution in their USP dissolution apparatus 2 in the range from 5-11 $\times 10^{-5} \mathrm{~m} \mathrm{~s}^{-1}$. Predicted mass-transfer coefficients using CFD for salicylic acid tablet dissolution were in the range from $1-6 \times 10^{-5} \mathrm{~m} \mathrm{~s}^{-1}$.

Hence, there appears to be some use for the benzoic acid (solute)/water (solvent) combination to probe the differences in external mass-transfer coefficients within a piece of equipment, but this solute/solvent combination does not appear to have been used to probe the differences in external mass-transfer coefficients between different types of equipment.

This work aims to use benzoic acid tablets to probe and compare the external masstransfer coefficients in two different types of dissolution apparatus, a simple beaker and 
stirrer system and the USP dissolution apparatus 2 (paddle), to assess the degree of similarity between the mass-transfer process in the two types of equipment. The key parameters that affect the mass-transfer coefficients are also assessed, together with the use of dimensional analysis to understand fundamental similarities and differences between the two types of equipment.

\section{Materials and Methods}

2.1. Experimental Approach

\subsubsection{Beaker and Stirrer System}

Benzoic acid (approximately $0.3 \mathrm{~g}$ ) was made into tablets with a diameter of $13 \mathrm{~mm}$ and an average height of $2.5 \mathrm{~mm}$ at a pressure of $111 \mathrm{MPa}$. The benzoic acid tablets were placed on a platform, which was $25 \mathrm{~mm}$ above the base of the beaker, as shown in Figure 1. This platform was constructed from polylactic acid (PLA) and fitted inside the beaker. The platform kept the tablet separated from contact with a magnetic stirrer at a well-defined distance in order to keep the shear stresses around the tablet reproducible, as shown in Figure 2, and the platform also prevented the tablet from moving randomly. The maximum volume of the beaker was $150 \mathrm{~mL}$, with a diameter of $56.3 \mathrm{~mm}$ and a height of $80.4 \mathrm{~mm}$. Different solution volumes $(80 \mathrm{~mL}$ and $120 \mathrm{~mL}$ ) were used, with different rotational speeds ( $0 \mathrm{rpm}, 100 \mathrm{rpm}$ and $200 \mathrm{rpm}$ ) for each magnetic stirrer. Different sizes of magnetic stirrer were used, and the detailed dimensions of the stirrers are given as shown in Figure 2.

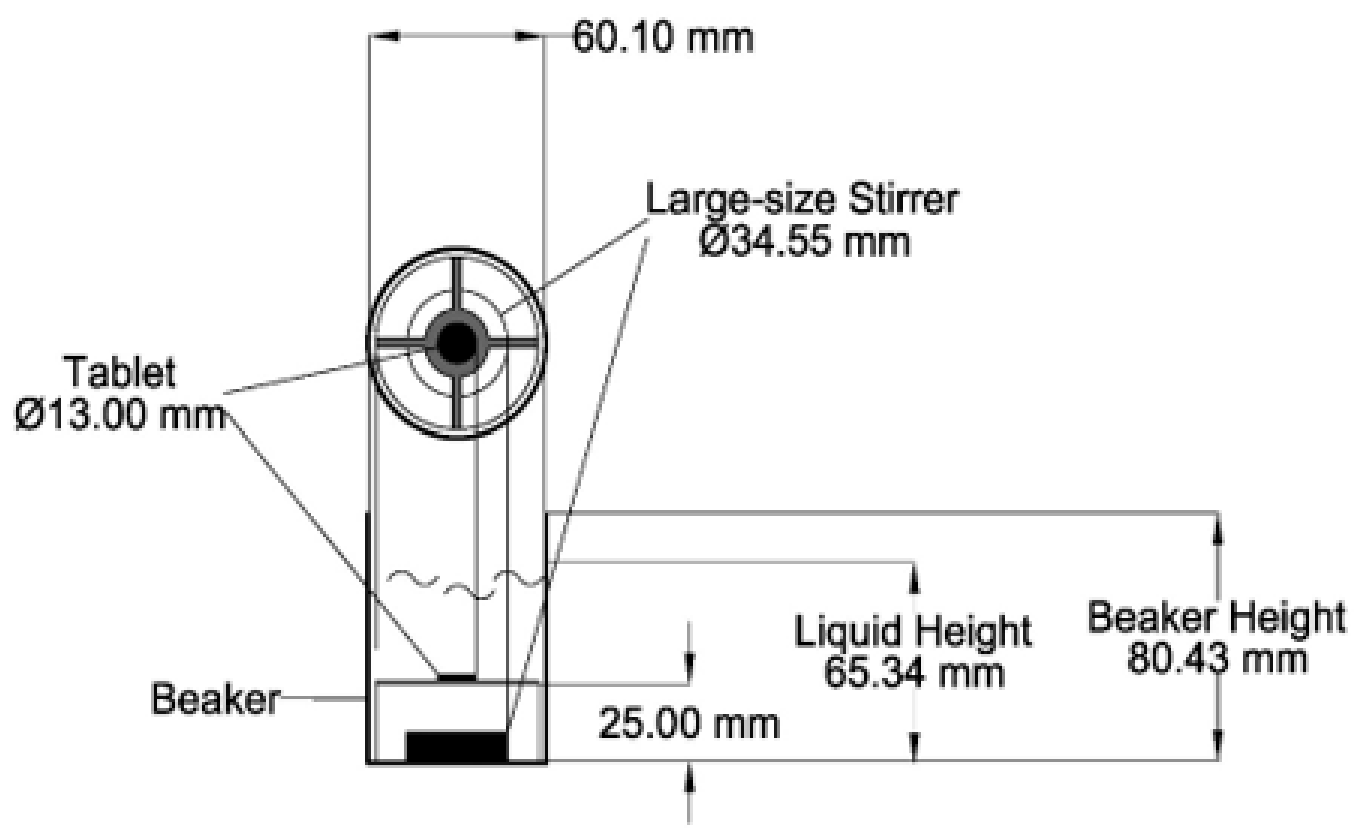

Figure 1. Schematic diagram of beaker and stirrer system.

The beaker was first filled with $80 \mathrm{~mL}$ or $120 \mathrm{~mL}$ of deionized water (DI water), and then the platform was placed into the beaker. The reason for using DI water is that it has no impurities that affect the UV spectroscopy results. Once the tablet was placed onto the platform, the hot plate and magnetic stirrer were turned on, and the rotational speed was set to 0,100 or $200 \mathrm{rpm}$. For the 100 and $200 \mathrm{rpm}$ conditions, samples were taken every two minutes, and three samples were taken in total. For the 0rpm condition, samples were taken every $10 \mathrm{~min}$, and three samples were taken in total. After all the samples were taken, UV spectroscopy was performed to measure the absorbance of each sample. Each experiment had at least two repeat trials. 


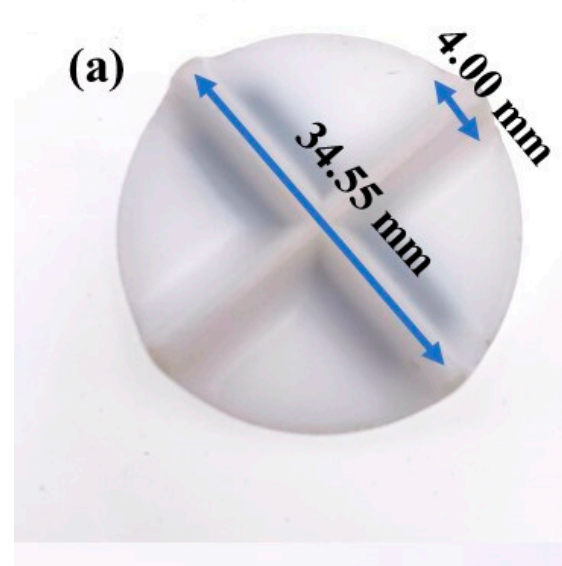

(c)

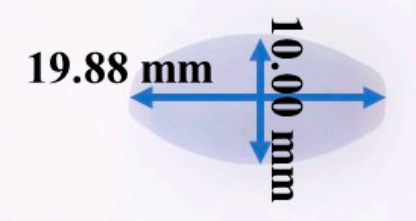

(b)

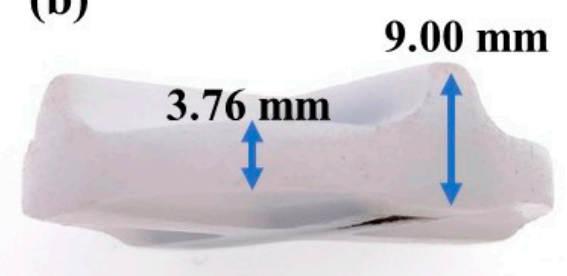

(d)

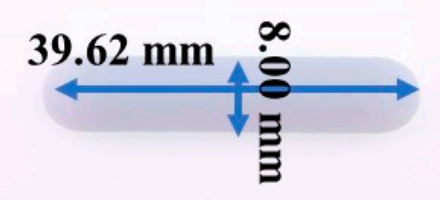

Figure 2. Images of the different stirrers: (a) plan view of stirrer 1 ; (b) elevation view of stirrer 1; (c) stirrer 2; (d) stirrer 3.

\subsubsection{USP Dissolution Apparatus 2}

USP dissolution apparatus 2 is a piece of paddle-type equipment, which is another kind of beaker system experiment that is widely used in the pharmaceutical industry $[13,14]$. The USP dissolution apparatus 2 (paddle) used here was manufactured by Agilent Varian VanKel, Santa Clara, California, USA, model VK 7000, with VanKel model 650A heater/circulator), as shown in Figure 3. The equipment is a standard piece of apparatus, for which the details and dimensions have been widely published [8,12,15-17]. The maximum volume of solution is $1 \mathrm{~L}$, with a diameter of $101 \mathrm{~mm}$ and a height of $165 \mathrm{~mm}$. The two-bladed paddle has a paddle diameter of $75 \mathrm{~mm}$ on the top of the paddle and $42 \mathrm{~mm}$ on its bottom edge.

The beaker was first filled with $200 \mathrm{~mL}$ or $900 \mathrm{~mL}$ DI water, and the rotational speed of the paddles was set to 0,50,100 or $200 \mathrm{rpm}$. Each experiment had two controlled trials. Once the paddle started to stir, tablets with the same size as those used in the beaker and stirrer system were placed into the equipment. All these experiments were operated at an average temperature of $21^{\circ} \mathrm{C}$. For the 50, 100, and $200 \mathrm{rpm}$ experiments, three samples were taken at $4 \mathrm{~min}, 8 \mathrm{~min}$, and $12 \mathrm{~min}$. For $0 \mathrm{rpm}$, three samples were taken after $1 \mathrm{~h}, 2 \mathrm{~h}$, and $3 \mathrm{~h}$, since the dissolution rate is lower and natural convection currents take a longer time to be established. After all the samples were taken, UV spectroscopy was used to measure the absorbance of each sample. 


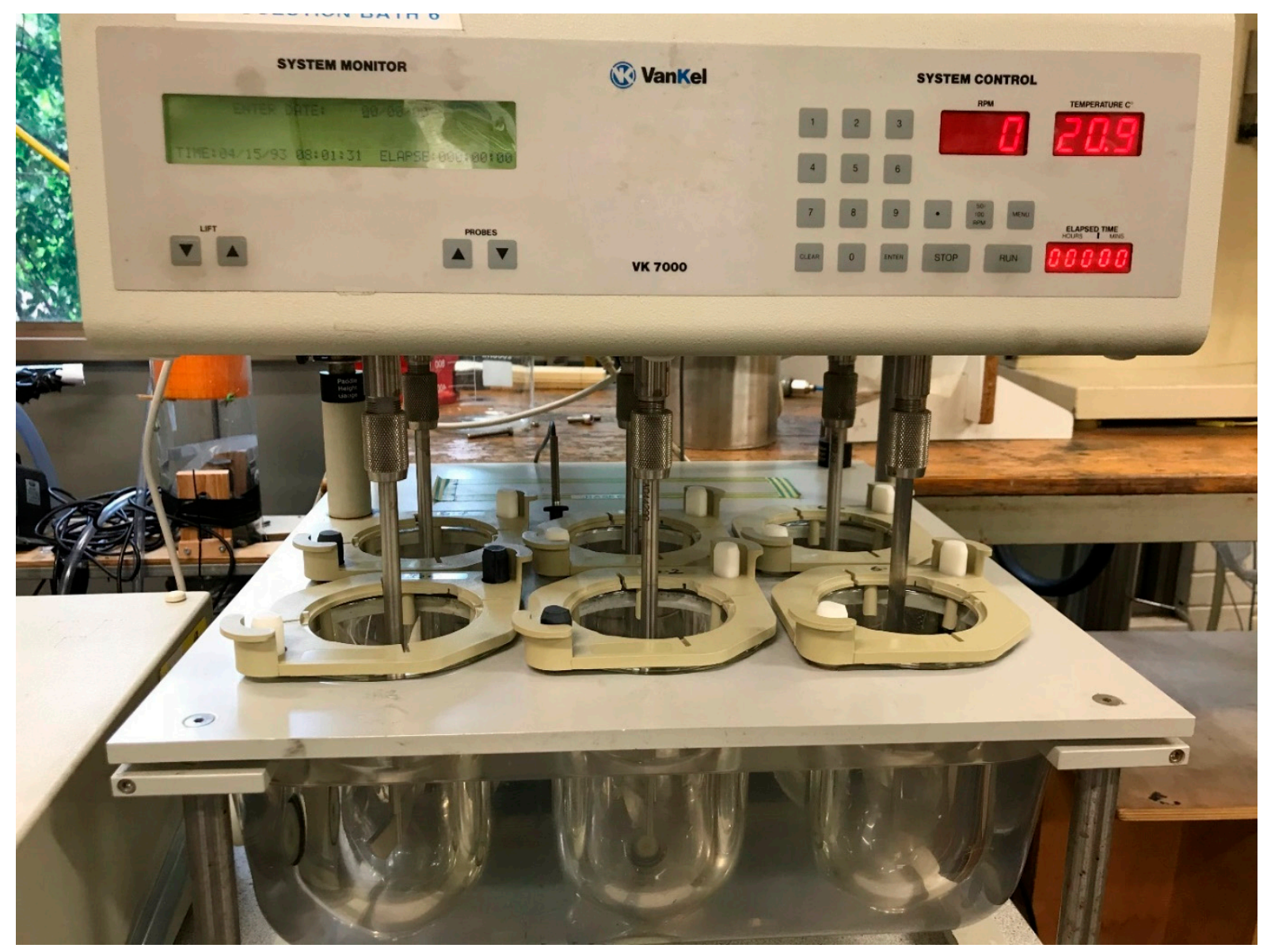

Figure 3. USP Dissolution Apparatus 2.

2.2. Data Analysis: Obtaining Mass-Transfer Coefficients and Shear Stresses from Solute Concentrations in a Solvent as a Function of Time and Unsteady-State Mass Balances

Starting with Equation (1), the rate of change of the concentration in the solution may be related to the mass transfer rate $\left(N_{A}\right)$ by the following unsteady-state mass balance equation:

$$
N_{A}=V \frac{d C_{b}}{d t}=K A\left(C_{s}-C_{b}\right)
$$

Here $V$ is the volume of solution $\left(\mathrm{m}^{3}\right)$, which may be kept constant by replacing the solution if sampling is carried out during an experiment, or the volume may not change very significantly during the experiment. As before, the interfacial contact area is given by the symbol $A\left(\mathrm{~m}^{2}\right)$. The overall mass-transfer coefficient $(K)$ is expressed in units of $\mathrm{m} \mathrm{s}^{-1}$ by dividing a mass-transfer coefficient in units of $\mathrm{kg} \mathrm{m}^{-2} \mathrm{~s}^{-1}$ by the density of the solution $\left(\mathrm{kg} \mathrm{m}^{-3}\right)$, while the concentration in Equation (2) has units of $\mathrm{kg}$ solute $\mathrm{m}^{-3}$ solution, so Equation (2) is dimensionally consistent, with the dissolution rate having units of $\mathrm{kg} \mathrm{s}^{-1}$. For a pure component (for example, a pure benzoic acid tablet), the external mass-transfer coefficient $(k)$ is the same as the overall mass-transfer coefficient $(K)$. Equation (2) may be integrated between $t=0, C_{b}=0$ and time $t$, concentration $C_{b}$, to give:

$$
\frac{C_{s}-C_{b}}{C_{s}}=\exp \left(-\frac{k A}{V} t\right)
$$

which can also be written in the form:

$$
C_{b}=C_{s}\left(1-e^{-\frac{t}{\tau}}\right)
$$


where a time constant for mass transfer $(\tau)$ may be defined (units of s) by the following equation:

$$
\tau=\frac{V}{k A}
$$

Equation (3) may be described as showing an exponential decay approach to saturation. Equation (2) may also be used to extract the overall mass-transfer coefficient from experimental measurements of bulk solution concentrations as functions of time, since the equation may be rearranged in the following form:

$$
\frac{d C_{b}}{d t}=\frac{k A}{V}\left(C_{s}-C_{b}\right)
$$

thus, the maximum rate of change for the bulk solution concentration $\left(d C_{b} / d t\right)$ may be related to the saturation concentration $\left(C_{S}\right)$, the overall mass-transfer coefficient $(k)$, the area of the food or tablet $(A)$ and the volume of the solution $(V)$ by the equation:

$$
\left(\frac{d C_{b}}{d t}\right)_{\max }=\frac{k A}{V} C_{s}
$$

knowing the area of the food or tablet $(A)$, the volume of the solution $(V)$ and the maximum rate of change for the bulk solution concentration (at the start of the experiment, $d C_{b} / d t$ ) allows the external mass-transfer coefficient $(k)$ to be estimated by rearranging Equation (7), as follows.

$$
k=\frac{V}{A C_{s}}\left(\frac{d C_{b}}{d t}\right)_{\max }
$$

\section{Results and Discussion}

\subsection{Mass-Transfer Coefficients}

The measured mass-transfer coefficients for the $0.3 \mathrm{~g}$ benzoic acid tablets dissolved in deionized water are given in Table 1 for the beaker and stirrer system and in Table 2 for the

\begin{tabular}{|c|c|c|c|c|c|c|}
\hline \multirow[b]{2}{*}{ Speed (rpm) } & \multicolumn{2}{|c|}{ Stirrer 1} & \multicolumn{2}{|c|}{ Stirrer 2} & \multicolumn{2}{|c|}{ Stirrer 3} \\
\hline & 80 & 120 & 80 & 120 & 80 & 120 \\
\hline 0 & $\begin{array}{l}5.21 \times 10^{-6} \\
4.55 \times 10^{-6}\end{array}$ & $\begin{array}{l}2.03 \times 10^{-6} \\
1.93 \times 10^{-6}\end{array}$ & & & & \\
\hline 100 & $\begin{array}{l}3.86 \times 10^{-5} \\
3.60 \times 10^{-5}\end{array}$ & $\begin{array}{l}2.30 \times 10^{-5} \\
2.27 \times 10^{-5}\end{array}$ & $\begin{array}{l}1.56 \times 10^{-5} \\
1.33 \times 10^{-5}\end{array}$ & $\begin{array}{l}6.95 \times 10^{-6} \\
5.69 \times 10^{-6}\end{array}$ & $\begin{array}{l}2.23 \times 10^{-5} \\
1.94 \times 10^{-5}\end{array}$ & $\begin{array}{l}2.22 \times 10^{-5} \\
2.09 \times 10^{-5}\end{array}$ \\
\hline 200 & $\begin{array}{l}4.48 \times 10^{-5} \\
4.33 \times 10^{-5}\end{array}$ & $\begin{array}{l}3.08 \times 10^{-5} \\
2.12 \times 10^{-5}\end{array}$ & $\begin{array}{l}1.87 \times 10^{-5} \\
1.48 \times 10^{-5}\end{array}$ & $\begin{array}{l}8.56 \times 10^{-6} \\
6.80 \times 10^{-6}\end{array}$ & $\begin{array}{l}3.47 \times 10^{-5} \\
3.44 \times 10^{-5}\end{array}$ & $\begin{array}{l}3.55 \times 10^{-5} \\
3.39 \times 10^{-5}\end{array}$ \\
\hline
\end{tabular}
USP dissolution apparatus 2.

Table 1. Mass-transfer coefficients $\left(\mathrm{m} \mathrm{s}^{-1}\right)$ for $0.3 \mathrm{~g}$ benzoic acid tablets dissolved in deionized water (beaker and stirrer system).

\begin{tabular}{|c|c|c|}
\hline Speed (rpm) & 200 & 900 \\
\hline 0 & $2.22 \times 10^{-6}, 2.85 \times 10^{-6}$ & $0.95 \times 10^{-6}, 0.95 \times 10^{-6}$ \\
\hline 50 & $1.74 \times 10^{-5}, 1.58 \times 10^{-5}$ & $1.40 \times 10^{-5}, 1.40 \times 10^{-5}$ \\
\hline 100 & $1.66 \times 10^{-5}, 1.81 \times 10^{-5}$ & $1.93 \times 10^{-5}, 1.80 \times 10^{-5}$ \\
\hline 200 & $\begin{array}{l}3.45 \times 10^{-5}, 3.18 \times 10^{-5} \\
2.82 \times 10^{-5}, 2.28 \times 10^{-5}\end{array}$ & $3.06 \times 10^{-5}, 2.78 \times 10^{-5}$ \\
\hline
\end{tabular}

Table 2. Mass-transfer coefficients $\left(\mathrm{m} \mathrm{s}^{-1}\right)$ for $0.3 \mathrm{~g}$ benzoic acid tablets dissolved in deionized water (USP dissolution apparatus 2). 
A noteworthy observation from Tables 1 and 2 is that the same mass-transfer coefficient may potentially be obtained from the same tablet in the two different devices with the use of different stirrers, rotational speeds, and volumes of solution. The range of mass-transfer coefficients measured in the beaker and stirrer system was $0.193-4.48 \times 10^{-5} \mathrm{~m} \mathrm{~s}^{-1}$, while the range measured in the USP dissolution apparatus 2 was $0.222-3.45 \times 10^{-5} \mathrm{~m} \mathrm{~s}^{-1}$, so there is significant overlap between the ranges of mass-transfer coefficients found in the two devices.

Our results in Table 2 for the USP dissolution apparatus 2 can be compared with some measurements of the mass-transfer rates in the literature by D'Arcy et al. [8] for this equipment under very similar conditions (50 rpm, $900 \mathrm{~mL})$, which can be converted to mass-transfer coefficients, as follows:

$(0.45-0.7) \mathrm{mg} / \mathrm{min} / \mathrm{cm}^{2}=(0.45-0.7) \times 10^{4} \mathrm{mg} / \mathrm{min} / \mathrm{m}^{2}=(0.45-0.7) \times 10^{4} / 10^{3} \mathrm{~g} / \mathrm{min} / \mathrm{m}^{2}$

$=(0.45-0.7) \times 10^{4} / 10^{3} / 60 \mathrm{~g} / \mathrm{s} / \mathrm{m}^{2} / \mathrm{Cs}$ at $37^{\circ} \mathrm{C}\left(5.014 \mathrm{~g} / \mathrm{L}=5014 \mathrm{~g} / \mathrm{m}^{3}\right)$

$=(1.5-2.3) \times 10^{-5} \mathrm{~m} \mathrm{~s}^{-1}$

This range of mass-transfer coefficients $\left((1.5-2.3) \times 10^{-5} \mathrm{~m} \mathrm{~s}^{-1}\right)$ from $\mathrm{D}^{\prime}$ Arcy et al. [8] is comparable with our results of $1.4 \times 10^{-5} \mathrm{~m} \mathrm{~s}^{-1}$ for these experimental conditions. The comparison may be even closer, when it is considered that the conversion requires the use of the saturation concentration at the experimental conditions $\left(37^{\circ} \mathrm{C}\right)$ of $\mathrm{D}^{\prime} \mathrm{Arcy}$ et al. [8], which has been assumed to be the same as that for benzoic acid in water at neutral conditions, here $5.014 \mathrm{~g} / \mathrm{L}$. The experimental conditions of D'Arcy et al. [8] were, in fact, 0.1 $\mathrm{M}$ hydrochloric acid, so the saturation concentration at $37^{\circ} \mathrm{C}$ for benzoic acid may have been slightly different, which would then give a slightly different range of mass-transfer coefficients to those calculated here $\left((1.5-2.3) \times 10^{-5} \mathrm{~m} \mathrm{~s}^{-1}\right)$. Hence there is some uncertainty in the conversion, due to the uncertainty in the saturation concentration of benzoic acid in $0.1 \mathrm{M} \mathrm{HCl}$. Williams et al. [18] have suggested that many drugs are more soluble in the highly acidic conditions of the stomach, and if the saturation concentration was $10 \%$ greater than that assumed here, then the range of mass-transfer coefficients calculated here $\left((1.5-2.3) \times 10^{-5} \mathrm{~m} \mathrm{~s}^{-1}\right)$ for the conditions of $\mathrm{D}^{\prime}$ Arcy et al. [8] would have been $10 \%$ lower, bringing them into a range that would include our results of $1.4 \times 10^{-5} \mathrm{~m} \mathrm{~s}^{-1}$ for these experimental conditions, suggesting that the measurements reported here are reasonable.

We note that, in doing experiments here at room temperature in water rather than $37^{\circ} \mathrm{C}$ in simulated gastric fluid (SGF), mass-transfer coefficients may be readily adjusted for the effects of temperature and fluid environment according to the differences in diffusivity between a solute (here benzoic acid) in water at room temperature and SGF at $37{ }^{\circ} \mathrm{C}$, since the Sherwood number is the mass transfer coefficient multiplied by the length scale (not affected by the temperature and fluid environment) and divided by the diffusivity (which is affected by the temperature and fluid environment). Hence the mass-transfer coefficient is virtually proportional to the diffusivity of the solute through the solvent, and if this difference in diffusivity is known, then the mass-transfer coefficients may be scaled appropriately. We suggest that doing experiments in this way can meet the aim of our study, which is to assess if the same mass-transfer coefficient can be obtained in different devices for the same tablet by adjusting the operating conditions and stirrer size and speed.

\subsection{Analysis of Variance (ANOVA) for the Mass-Transfer Coefficients}

The analysis of variance (ANOVA) table results from the $13 \mathrm{~mm}$ tablets with the platform, beaker and stirrer (Table 1) is given in Table 3. From Table 3, for the beaker and stirrer system, almost all the effects and interactions are significant at the $95 \%$ confidence level, except for the two-way interaction between stirrer speed and solution volume, and (marginally for) the three-way interaction between stirrer speed, stirrer type, and solution volume. The stirrer speed affects the Reynolds number for the stirrer and hence is expected to affect the mass-transfer coefficients for the tablets. The stirrer type and size, as well as the volume, might also reasonably be expected to affect the flow patterns in the beaker and hence the shear stresses and strain rates that in turn would also be expected to affect the 
mass-transfer coefficients for the tablets. Here MS(error) $=6.96 \times 10^{-12}=$ variance, so the standard error is $\mathrm{s}=\sqrt{6.96 \times 10^{-12}}=2.64 \times 10^{-6} \mathrm{~m} \mathrm{~s}^{-1}$.

Table 3. ANOVA for the mass-transfer coefficients from the $13 \mathrm{~mm}$ platform, beaker, and stirrer $\left({ }^{*}\right.$ means significant at $95 \%$ confidence level).

\begin{tabular}{|c|c|c|c|c|c|}
\hline Source of Variation & $\begin{array}{l}\text { Degrees of } \\
\text { Freedom (df) }\end{array}$ & $\begin{array}{l}\text { Sum of Squares } \\
\text { (SoS) }\end{array}$ & $\begin{array}{l}\text { Mean Square } \\
\text { (MS) }\end{array}$ & $\begin{array}{l}\text { Actual } \\
\text { F-Value }\end{array}$ & $\begin{array}{c}\text { Test F-Value, } \\
95 \%\end{array}$ \\
\hline Stirrer speed & 2 & $1.71 \times 10^{-9}$ & $8.57 \times 10^{-10}$ & 123.1 & $4.1^{*}$ \\
\hline Stirrer type & 2 & $1.18 \times 10^{-9}$ & $5.88 \times 10^{-10}$ & 84.4 & $4.1 *$ \\
\hline Volume of solution & 1 & $3.83 \times 10^{-10}$ & $3.83 \times 10^{-10}$ & 55.1 & $5.0 *$ \\
\hline $\begin{array}{l}\text { Interaction: stirrer speed } \times \\
\text { stirrer type }\end{array}$ & 4 & $9.65 \times 10^{-10}$ & $2.41 \times 10^{-10}$ & 34.7 & $3.5^{*}$ \\
\hline $\begin{array}{l}\text { Interaction: stirrer speed } \times \\
\text { volume of solution }\end{array}$ & 2 & $2.78 \times 10^{-11}$ & $1.39 \times 10^{-11}$ & 2.0 & 4.1 \\
\hline $\begin{array}{l}\text { Interaction: stirrer type } \times \\
\text { volume of solution }\end{array}$ & 2 & $1.84 \times 10^{-10}$ & $9.19 \times 10^{-11}$ & 13.2 & $4.1 *$ \\
\hline $\begin{array}{l}\text { Interaction: stirrer speed } \times \text { stirrer } \\
\text { type } \times \text { volume of solution }\end{array}$ & 4 & $9.80 \times 10^{-11}$ & $2.45 \times 10^{-11}$ & 3.5 & 3.5 \\
\hline Error & 10 & $6.96 \times 10^{-11}$ & $6.96 \times 10^{-12}$ & & \\
\hline Total & 27 & $4.62 \times 10^{-9}$ & & & \\
\hline
\end{tabular}

The analysis of variance (ANOVA) table results from the $13 \mathrm{~mm}$ tablets with the USP dissolution apparatus 2 (Table 2) is given in Table 4 . Here, MS(error) $=8.41 \times 10^{-12}=$ variance, so the standard error is $\mathrm{s}=\sqrt{8.41 \times 10^{-12}}=2.90 \times 10^{-6} \mathrm{~m} \mathrm{~s}^{-1}$. Only the effect of stirrer speed appears to be significant in the USP dissolution apparatus 2 (paddle). This finding is consistent with the predictions of the CFD simulations by Bai et al. [13], who found that there were two basic regions or zones for the flow patterns in the device, being recirculation zones below and above the paddle. Therefore, since the tablet typically remains in the recirculation zone below the paddle, the effect of the volume of solution on the mass-transfer coefficients for tablets below the stirrer should be small, as observed, provided that there is enough solution to cover the paddle, as was the case for the measurements with $200 \mathrm{~mL}$ of water in this work.

Table 4. ANOVA for the mass-transfer coefficients from the $13 \mathrm{~mm}$ tablets, USP dissolution apparatus 2 (paddle) $\left({ }^{*}\right.$ means significant at $95 \%$ confidence level).

\begin{tabular}{|c|c|c|c|c|c|}
\hline Source of Variation & $\begin{array}{l}\text { Degrees of } \\
\text { Freedom (df) }\end{array}$ & $\begin{array}{c}\text { Sum of Squares } \\
\text { (SoS) }\end{array}$ & $\begin{array}{l}\text { Mean Square } \\
\text { (MS) }\end{array}$ & $\begin{array}{l}\text { Actual } \\
\text { F-Value }\end{array}$ & Test F-Value, 95\% \\
\hline Stirrer speed & 3 & $1.84 \times 10^{-9}$ & $6.15 \times 10^{-10}$ & 73.1 & $3.7 *$ \\
\hline Volume of solution & 1 & $1.11 \times 10^{-11}$ & $1.11 \times 10^{-11}$ & 1.3 & 5.0 \\
\hline $\begin{array}{l}\text { Interaction: stirrer speed } \\
\times \text { volume of solution }\end{array}$ & 3 & $9.99 \times 10^{-15}$ & $3.33 \times 10^{-15}$ & $<0.01$ & 3.7 \\
\hline Error & 10 & $8.41 \times 10^{-11}$ & $8.41 \times 10^{-12}$ & & \\
\hline Total & 17 & $1.94 \times 10^{-9}$ & & & \\
\hline
\end{tabular}

Significant variability in dissolution times has been widely reported with the USP dissolution apparatus 2 (paddle) due to the tendency of the tablet to move into different regions of the equipment where there are different shear stresses and shear rates $[12,14-17,19,20]$. This greater variability can also be seen in the analysis of variance in Table 3 (beaker and stirrer) and Table 4 (USP dissolution apparatus 2), where the standard error for the USP 
dissolution apparatus 2 of $2.90 \times 10^{-6} \mathrm{~m} \mathrm{~s}^{-1}$ is greater than that from the beaker and stirrer system of $2.64 \times 10^{-6} \mathrm{~m} \mathrm{~s}^{-1}$.

\subsection{Dimensional Analysis}

The mass-transfer coefficients measured here in Tables 1 and 2 have been further analysed by dimensional analysis, with the physical property data given in the Supplementary material. Particularly important dimensionless groups for mass transfer include the Sherwood (Sh), Reynolds (Re), and Schmidt (Sc) numbers. The Sherwood number includes the ratio of the convective mass transfer flux to the molecular diffusion of a mass component, while the Reynolds number includes the ratio of the inertial to the viscous stresses, and the Schmidt number is the ratio of the molecular diffusion of momentum to the molecular diffusion of a mass component. These dimensionless groups for mass transfer $(S h, R e, S c)$ have been defined as follows:

$$
\begin{gathered}
S h=\frac{k L}{D} \\
R e=\frac{\rho u L}{\mu} \\
S c=\frac{\mu}{\rho D}
\end{gathered}
$$

where $L$ is the length scale $(\mathrm{m})$ for the dissolution, here taken as the tablet outer diameter $(\mathrm{d})$, $13 \mathrm{~mm}(0.013 \mathrm{~m}), k$ is the external mass-transfer coefficient $\left(\mathrm{m} \mathrm{s}^{-1}\right)$ from these experiments, and $u$ is the characteristic velocity $\left(\mathrm{m} \mathrm{s}^{-1}\right.$ ) in the system (here taken as being proportional to the impeller tip speed). The physical properties (estimated as stated in the Supplementary material) include the solution density, $\rho\left(\mathrm{kg} \mathrm{m}^{-3}\right)$, the solution viscosity, $\mu\left(\mathrm{kg} \mathrm{m}^{-1} \mathrm{~s}^{-1}\right)$, and the diffusivity of the solute (benzoic acid) through the solvent (water), $D\left(\mathrm{~m}^{2} \mathrm{~s}^{-1}\right)$. The impeller tip speed is $\mathrm{Nd} / 2$, where $\mathrm{N}$ is the rotational speed of the stirrer $\left(\mathrm{s}^{-1}\right)$, and $\mathrm{d}$ is the stirrer outer diameter $(\mathrm{m})$.

The form of the mass-transfer correlations for liquid-solid interfaces listed in Table 8.3-3 of Cussler [1] generally follow the pattern shown below:

$$
S h=a+b R e^{c} S c^{1 / 3}
$$

with a common correlation for particles and flow around particles and droplets as individual objects being the Ranz-Marshall correlation [21], having $a=2, b=0.6$, and $c=0.5$. This correlation has been used in several simulations of spray dryer behaviour [22,23]. It is therefore interesting to see that it predicts Sherwood numbers for tablets dissolving in liquids (Figure 4, beaker and stirrer system; Figure 5, USP dissolution apparatus 2) that are of the same order of magnitude as those for particles and droplets in spray dryers, despite the length scales of the particles and droplets, as well as the densities of the air and the liquid used here, being three orders of magnitude different to those in this tablet dissolution. This similarity is due to the same basic physical situation being present in both cases, namely a fluid flowing around an object.

\subsection{Overall Discussion: External Mass Transfer Coefficients, Time Constants and Other Literature}

We start here from Equation (5), where a time constant for mass transfer $(\tau, \mathrm{s})$ may be defined in terms of the mass-transfer coefficient $\left(\mathrm{k}, \mathrm{m} \mathrm{s}^{-1}\right)$, the volume of solution $\left(\mathrm{V}, \mathrm{m}^{3}\right)$, and the interfacial surface area $\left(\mathrm{A}, \mathrm{m}^{2}\right), \tau=\mathrm{V} /(\mathrm{A} \mathrm{k})$. The significance of a time constant is that it is a characteristic time for the dynamics of a system, here one for mass transfer, where the larger the time constant, the more rate limiting is the mass-transfer process. It is meaningful to compare a time constant (for mass transfer) with a reaction time to estimate if the overall process of mass transfer for reactants to move towards each other, and then react, and then for the products to move away from the reaction site, is limited by the mass-transfer process or the reaction. 


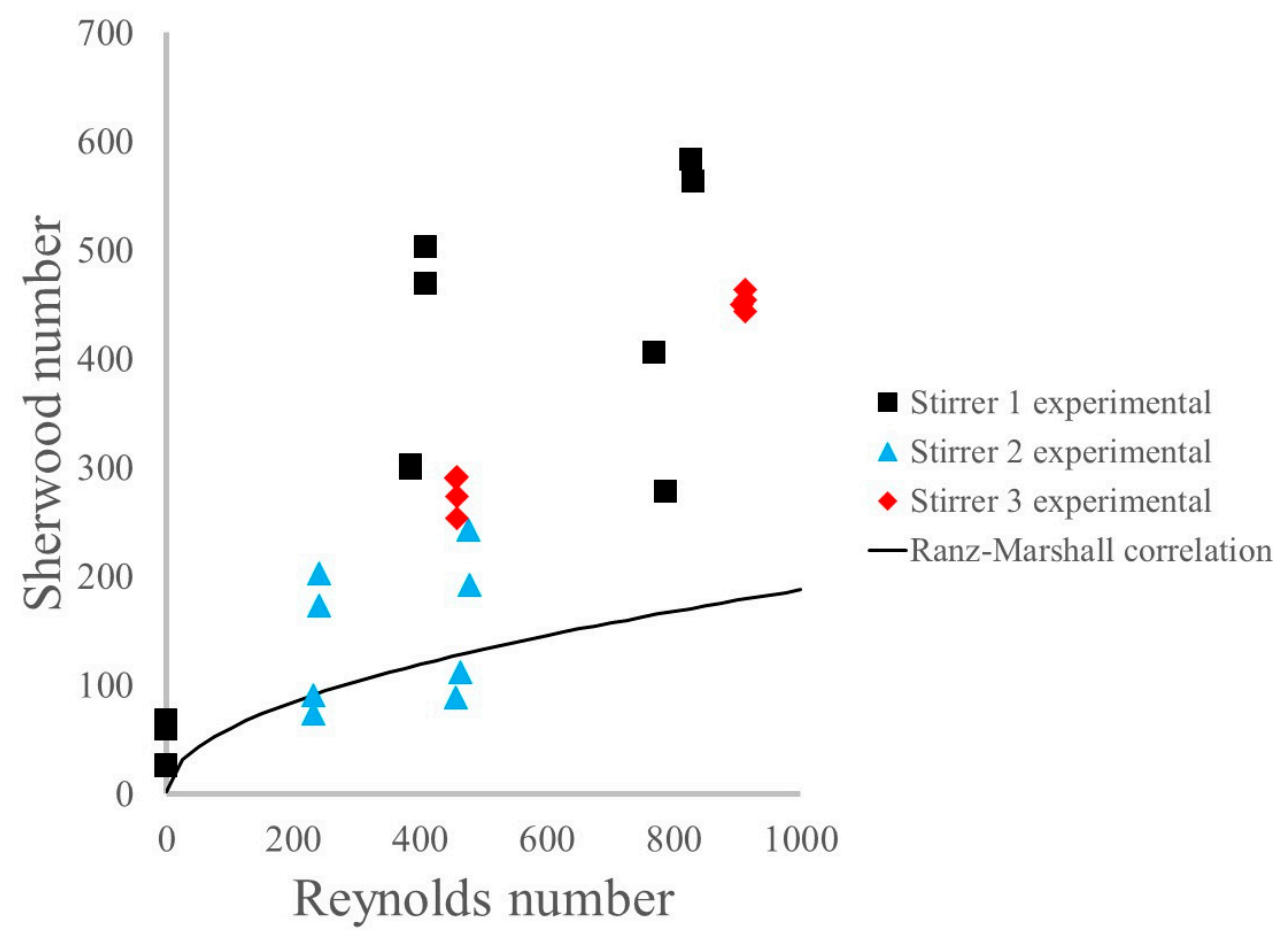

Figure 4. Sherwood number as a function of Reynolds number for beaker and stirrer apparatus.

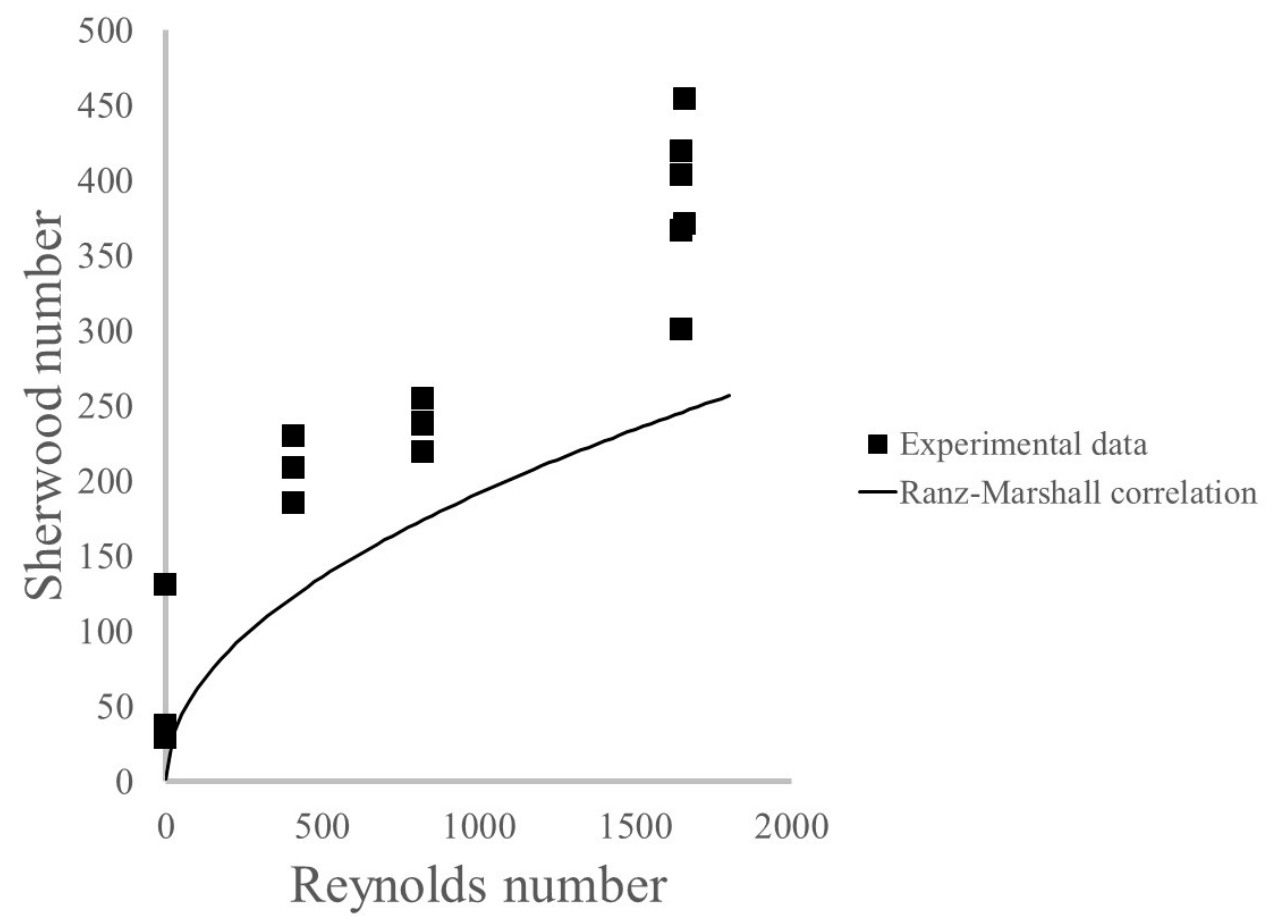

Figure 5. Sherwood number as a function of Reynolds number for USP dissolution apparatus 2.

Hence the time constant for mass transfer in digestion can reasonably be compared with the time for reactions that occur during digestion. An example of such a digestive reaction is where amylose and amylopectin, which are key components of starch and consist of glucose monomers that are connected together in different ways, are broken down into maltose or their glucose subunits, usually by the enzyme (biochemical catalyst) amylase. It is relevant to ask if the reaction rate is likely to be limited by the mass-transfer rate of amylase towards the reaction site (amylopectin or amylase) or the reaction itself. This reaction is involved in fermentation, and fermentation times typically range from 
2-8 days [24]. At the same time, Li et al. [25] show time scales of up to $500 \mathrm{~min}$ for starch breakdown by amylase, with significant changes in the first hour, so time scales of hours to days appear to be typical for the starch breakdown reaction.

The time constants (in hours) for the different volumes and mass-transfer coefficients from Table 1, for the beaker and stirrer system, and Table 2, for the USP dissolution apparatus 2, are shown in Tables 5 and 6, respectively. These time constants are very considerable, particularly relative to the reactions that occur during digestion, indicating that the external mass-transfer behaviour cannot be reasonably ignored or neglected during dissolution processes.

Table 5. Mass-transfer time constants (hours) for $0.3 \mathrm{~g}$ benzoic acid tablets dissolved in deionized water (beaker and stirrer system).

\begin{tabular}{|c|c|c|c|c|c|c|}
\hline \multirow[b]{2}{*}{$\begin{array}{l}\text { Volume }(\mathrm{mL}) \\
\text { Speed (rpm) }\end{array}$} & \multicolumn{2}{|c|}{ Stirrer 1} & \multicolumn{2}{|c|}{ Stirrer 2} & \multicolumn{2}{|c|}{ Stirrer 3} \\
\hline & 80 & 120 & 80 & 120 & 80 & 120 \\
\hline 0 & $22.0,25.2$ & $84.6,89.0$ & & & & \\
\hline 100 & $3.0,3.2$ & $7.5,7.6$ & $7.3,8.6$ & $24.7,30.2$ & $5.1,5.9$ & $7.7,8.2$ \\
\hline 200 & $2.6,2.6$ & $5.6,8.1$ & $6.1,7.7$ & $20.1,25.3$ & $3.3,3.3$ & $4.8,5.2$ \\
\hline
\end{tabular}

Table 6. Mass-transfer time constants (hours) for $0.3 \mathrm{~g}$ benzoic acid tablets dissolved in deionized water (USP dissolution apparatus 2).

\begin{tabular}{ccc}
\hline Volume $(\mathbf{m L})$ & $\mathbf{2 0 0}$ & $\mathbf{9 0 0}$ \\
\hline 0 & & 1295,1295 \\
50 & $16.0,100.5$ & $92.1,92.1$ \\
100 & $17.3,15.8$ & $66.8,71.6$ \\
200 & $8.3,9.0,10.2,12.6$ & $42.1,46.4$ \\
\hline
\end{tabular}

In Table 6, the reason for the large difference in the mass-transfer time constants for zero rotation speed compared with the non-zero speeds, particularly in the USP dissolution apparatus 2, arises for the following reason. The formula for the mass-transfer time constants is $\tau=V /(A \mathrm{k})$, where the symbols are the mass-transfer coefficient $\left(\mathrm{k}, \mathrm{m} \mathrm{s}^{-1}\right)$, the volume of solution $\left(\mathrm{V}, \mathrm{m}^{3}\right)$, and the interfacial surface area $\left(\mathrm{A}, \mathrm{m}^{2}\right)$. The mass-transfer time constant is therefore proportional to the ratio of $\mathrm{V}$ (the volume) to $\mathrm{k}$ (the mass-transfer coefficient), so any difference in the time constant depends on how the mass-transfer coefficient changes at the same time as the volume changes in any type of apparatus. The mass-transfer coefficient is likely to depend on the flow pattern. At zero rotation speed, the spinning impeller, in the USP dissolution apparatus 2, no longer has the effect of dividing the total volume into two sections, one above and the other below the impeller. The whole volume then becomes affected by the natural convection circulation pattern, in contrast to the situation with the impeller, where the whole volume is split into two effective sections by the impeller.

It is worth noting that the mass-transfer time constant becomes much smaller (and mass transfer less significant as a limitation) for smaller particles. Particles of sizes greater than $0.3 \mathrm{~mm}$ in digestion are mentioned by Lentle and Janssen [26]. These particles have a surface area per unit volume of $6 /\left(0.3 \times 10^{-3} \mathrm{~m}\right)=2 \times 10^{4} \mathrm{~m}^{-1}$. For a $100 \mathrm{~mL}$ volume of food, the total surface area would be $A=2 \times 10^{4} \mathrm{~m}^{-1 \times} 100 \times 10^{-6} \mathrm{~m}^{3}=2 \mathrm{~m}^{2}$. With a very small particle, and a very low particle Reynolds number, the smallest Sherwood number (Ranz-Marshall correlation) is 2, so the mass-transfer coefficient for benzoic acid in water would be $\mathrm{k}=2 \times 1 \times 10^{-9} \mathrm{~m}^{2} \mathrm{~s}^{-1} /\left(0.3 \times 10^{-3} \mathrm{~m}\right)=6.67 \times 10^{-6} \mathrm{~m} \mathrm{~s}^{-1}$. If the volume of solution is $\mathrm{V}=0.9 \times 10^{-3} \mathrm{~m}^{3}(900 \mathrm{~mL})$, then the time constant would be $\tau=0.9 \times 10^{-3} \mathrm{~m}^{3} /\left(2 \mathrm{~m}^{2} \times 6.67 \times 10^{-6} \mathrm{~m} \mathrm{~s}^{-1}\right)=67.5 \mathrm{~s}$. This time constant is quite short compared with the reaction processes mentioned above. 
However, $0.3 \mathrm{~mm}$ particles are very small, and the pyloris can let millimetre size particles through to the small intestine [27]. Repeating the calculations above with $3 \mathrm{~mm}$ diameter particles gives a time constant of $6750 \mathrm{~s}$, due to the combined effects of particle size in reducing the surface area per unit volume and reducing the mass-transfer coefficient. This time constant is much larger than that for the $0.3 \mathrm{~mm}$ diameter particle, emphasizing the combined effects of particle size and mass transfer on the importance of the external mass-transfer resistance.

As noted in the introduction, other measurements of mass-transfer coefficients in the literature include the small intestine geometry $\left(0.5-3.4 \times 10^{-6} \mathrm{~m} \mathrm{~s}^{-1}\right)$ of Tharakan et al. [11], and the salicyclic acid tablet dissolution measurements $\left(5-11 \times 10^{-5} \mathrm{~m} \mathrm{~s}^{-1}\right)$ and CFD predictions (1-6 $\times 10^{-5} \mathrm{~m} \mathrm{~s}^{-1}$ ) of Bai and Armenante [12] in a USP dissolution apparatus 2. Other dissolution rate measurements may also be analysed further and should be included here.

D'Arcy et al. [9] did an evaluation of the hydrodynamics in the USP dissolution apparatus 1 (basket) using benzoic acid tablets with a surface area of $3.88 \times 10^{-4} \mathrm{~m}^{2}$ in $0.9 \mathrm{~L}$ of $0.1 \mathrm{M}$ hydrochloric acid. The rotational speed of the baskets was $50 \mathrm{rpm}$. The maximum rate of mass loss was $0.001196 \mathrm{~g} \mathrm{~s}-1$, and the saturation concentration of benzoic acid was $4.564 \mathrm{~g} \mathrm{~L}^{-1}$, or $4564 \mathrm{~g} \mathrm{~m}^{-3}$, so the mass-transfer coefficient could be estimated as $\mathrm{k}=0.001196 \mathrm{~g} \mathrm{~s}^{-1} /\left(3.88 \times 10^{-4} \mathrm{~m}^{2 \times} 4564 \mathrm{~g} \mathrm{~m}^{-3}\right)=6.76 \times 10^{-4} \mathrm{~m} \mathrm{~s}^{-1}$.

Some measurements of the mass-transfer rates from tablets containing theophylline have been given in the literature by Raslan and Maswadeh [28], which can be converted to mass-transfer coefficients, as follows. The reported rate of release for any tablet was 50\% in $30 \mathrm{~min}$, and each tablet contained $300 \mathrm{mg}$ of theophylline, so $150 \mathrm{mg}$ of theophylline was released in $30 \mathrm{~min}$, giving a release rate of $0.15 \mathrm{~g} /(30 \times 60 \mathrm{~s})$ in $0.9 \mathrm{~L}$ of solution, or $(\mathrm{d} \mathrm{C} / \mathrm{d} \mathrm{t}) 9.26 \times 10^{-5} \mathrm{~g} \mathrm{~L}^{-1} \mathrm{~s}^{-1}$. The tablets were $13 \mathrm{~mm}$ in diameter, and the thickness was not reported. However, a tablet thickness of $3 \mathrm{~mm}$ would be a reasonable estimate, given that the tablet mass was $700 \mathrm{mg}$, since a $3 \mathrm{~mm}$ thick tablet would have a volume of $\pi / 4(13 \mathrm{~mm})^{2} \times 3 \mathrm{~mm}=398 \mathrm{~mm}^{3}$, giving a tablet density of $1.75 \mathrm{mg} \mathrm{mm}^{-3}$ or $1.75 \mathrm{~g} \mathrm{cc}^{-1}$, which is not an unusual value for the compressed tablet density. A $3 \mathrm{~mm}$ thick tablet with a diameter of $13 \mathrm{~mm}$ would have a total surface area (A) of $387 \mathrm{~mm}^{2}$ or $0.000387 \mathrm{~m}^{2}$. A USP dissolution apparatus 2 was used with a volume of solution (V) of $0.9 \mathrm{~L}$ or $0.0009 \mathrm{~m}^{3}$. Finally, the saturation concentration (solubility) of theophylline in water at $25^{\circ} \mathrm{C}$ was reported by Martin et al. [29] to be a molar concentration (moles theophylline/total moles) of 0.0007414 . Given the molecular weight of water $\left(18.02 \mathrm{~g} \mathrm{~mol}^{-1}\right)$, the density of water $\left(1 \mathrm{~g} \mathrm{~mL}^{-1}\right)$ and the molecular weight of theophylline $\left(180.16 \mathrm{~g} \mathrm{~mol}^{-1}\right)$, the saturation concentration $\left(\mathrm{C}_{\mathrm{sat}}\right)$ of theophylline in water at $25^{\circ} \mathrm{C}$ is $180.16 \mathrm{~g} \mathrm{~mol}^{-1} \times 0.0007414$ / (1-0.0007414) moles theophylline/mole water $\times 1000 \mathrm{~g} \mathrm{~L}^{-1} / 18.02 \mathrm{~g} \mathrm{~mol}^{-1}$ water $=7.42 \mathrm{~g} \mathrm{~L}^{-1}$ Then, an estimate of the mass-transfer coefficient is given by $\mathrm{k}=0.0009 \mathrm{~m}^{3} /\left(0.000387 \mathrm{~m}^{2}\right)$ $\times 9.26 \times 10^{-5} \mathrm{~g} \mathrm{~L}^{-1} \mathrm{~s}^{-1} /\left(7.42 \mathrm{~g} \mathrm{~L}^{-1}\right)=2.9 \times 10^{-5} \mathrm{~m} \mathrm{~s}^{-1}$.

Williams et al. [18] investigated the release of $10 \mathrm{mg}$ alprazolam from $11 \mathrm{~mm}$ diameter, $400 \mathrm{mg}$ tablets, which would have had a thickness of $2.1 \mathrm{~mm}$ if the tablet density were $2000 \mathrm{~kg} \mathrm{~m}^{-3}$, and a surface area of $2.63 \times 10^{-4} \mathrm{~m}^{2}$. The solubility of alprazolam in $0.1 \mathrm{~N}$ hydrochloric acid was stated to be $12 \mathrm{mg} \mathrm{mL}^{-1}$ or $12,000 \mathrm{~g} \mathrm{~m}^{-3}$, and the maximum dissolution rate was $20 \%$ of the $10 \mathrm{mg}$ alprazolam in $1 \mathrm{~min}$, giving a dissolution rate of $0.2 \times 10^{-2} \mathrm{~g} / 60 \mathrm{~s}=3.33 \times 10^{-5} \mathrm{~g} \mathrm{~s}^{-1}$. From this, an estimate of the mass-transfer coefficient is given by $\mathrm{k}=1 /\left(2.63 \times 10^{-4} \mathrm{~m}^{2}\right) \times 3.33 \times 10^{-5} \mathrm{~g} \mathrm{~s}^{-1} /\left(12,000 \mathrm{~g} \mathrm{~m}^{-3}\right)=1.06 \times 10^{-5} \mathrm{~m} \mathrm{~s}^{-1}$.

Reviewing all these measurements, the typical range of external mass-transfer coefficients from tablets in digestion systems lies in the range of $1-100 \times 10^{-6} \mathrm{~m} \mathrm{~s}^{-1}$. From the dimensional analysis in this work, the Sherwood numbers from the Ranz-Marshall correlation appear to be underestimates of the experimental values, so that $S h=2-1000$. In addition, the particle sizes for food digestion may lie in the range from $0.1 \mathrm{~mm}$ to $13 \mathrm{~mm}$ (and smaller sizes have lower Reynolds numbers and hence Sherwood numbers), with diffusivities of the order of $10^{-9} \mathrm{~m}^{2} \mathrm{~s}^{-1}$, so this range of external mass-transfer coefficients is not surprising. 


\section{Conclusions}

With the external mass-transfer coefficients ranging from $0.193-4.48 \times 10^{-5} \mathrm{~m} \mathrm{~s}^{-1}$ in the beaker and stirrer system and $0.222-3.45 \times 10^{-5} \mathrm{~m} \mathrm{~s}^{-1}$ in the USP dissolution apparatus 2, there was considerable overlap between the coefficients measured in both devices. This situation allows the same coefficient to be obtained in both devices for the same tablet by adjusting the operating conditions and stirrer size and speed. The credibility of these coefficients is increased by the finding that previous literature found, at the same operating conditions and with the same size and composition of tablet, the same external mass-transfer coefficient of that measured here with the USP dissolution apparatus 2 within $10 \%$ despite the difference in solution $\mathrm{pH}$ between our study and previous work. Analysis of variance (ANOVA) showed that the external mass-transfer coefficients were significantly affected with $95 \%$ confidence in the beaker and stirrer system by the stirrer type, size and speed, and the solution volume, while these coefficients in the USP dissolution apparatus 2 were affected at the same level of confidence by only the stirrer speed. It has been shown, using dimensional analysis, that a lower bound for estimates of the experimental Sherwood numbers is given by the Ranz-Marshall correlation. Under some conditions, estimates made here of mass-transfer time constants suggest that it is possible that mass transfer may be a rate-limiting process in dissolution and food digestion systems. The Ranz-Marshall correlation suggests mass-transfer coefficients in the range of $1-100 \times 10^{-6} \mathrm{~m} \mathrm{~s}^{-1}$, as found here $\left(0.193-4.48 \times 10^{-5} \mathrm{~m} \mathrm{~s}^{-1}\right.$, beaker and stirrer system; $0.222-3.45 \times 10^{-5} \mathrm{~m} \mathrm{~s}^{-1}$, USP dissolution apparatus 2), which also covers the range of coefficients found in the literature.

Supplementary Materials: The following are available online at https:/ / www.mdpi.com/article / 10.3390/pr9122168/s1, Table S1: Corresponding temperatures for the experiments that measured the mass-transfer coefficients in Table 1 (Beaker and stirrer system). Table S2: Corresponding temperatures for the experiments that measured the mass-transfer coefficients in Table 2 (USP dissolution apparatus 2). Reference [30] is cited in the supplementary materials.

Author Contributions: Conceptualization, T.A.G.L.; methodology, T.A.G.L. and C.Z.; software, T.A.G.L.; validation, T.A.G.L. and C.Z.; formal analysis, T.A.G.L., C.Z. and L.S.; investigation, C.Z. and L.S.; resources, T.A.G.L.; data curation, T.A.G.L., C.Z. and L.S.; writing-original draft preparation, T.A.G.L., C.Z. and L.S.; writing-review and editing, T.A.G.L. and C.Z.; visualization, T.A.G.L., C.Z. and L.S.; supervision, T.A.G.L.; project administration, T.A.G.L.; funding acquisition, T.A.G.L. All authors have read and agreed to the published version of the manuscript.

Funding: This research received no external funding.

Conflicts of Interest: The authors declare no conflict of interest.

\section{References}

1. Cussler, E.L. Diffusion: Mass Transfer in Fluid Systems, 2nd ed.; Cambridge University Press: Cambridge, UK, 1997; ISBN 9780521871211.

2. Chhabra, R.P.; Shankar, V. Coulson and Richardson's Chemical Engineering Volume 1B: Heat and Mass Transfer-Funda-mentals and Applications. In Butterworth-Heinemann, 7th ed.; Elsevier: Amsterdam, The Netherlands, 2018; ISBN 9780081025505.

3. Irandoust, S.; Andersson, B. Concentration-dependent diffusivity of benzoic acid in water and its influence on the liquid-solid mass transfer. Can. J. Chem. Eng. 1986, 64, 954-959. [CrossRef]

4. Chan, A.F.; Evans, D.F.; Cussler, E.L. Explaining solubilization kinetics. AIChE J. 1976, 22, 1006-1012. [CrossRef]

5. Ding, H.; Cussler, E.L. Fractional extraction with hollow fibers with hydrogel-filled walls. AIChE J. 1991, 37, 855-862. [CrossRef]

6. Tao, J.C.; Cussler, E.L.; Evans, D.F. Accelerating Gallstone Dissolution. Proc. Natl. Acad. Sci. USA 1974, 71, 3917-3921. [CrossRef] [PubMed]

7. Hunek, B.; Cussler, E.L. Mechanisms of photoresist dissolution. AIChE J. 2002, 48, 661-672. [CrossRef]

8. D'Arcy, D.; Corrigan, O.I.; Healy, A.M. Hydrodynamic simulation (computational fluid dynamics) of asymmetrically positioned tablets in the paddle dissolution apparatus: Impact on dissolution rate and variability. J. Pharm. Pharmacol. 2005, 57, 1243-1250. [CrossRef] [PubMed]

9. D'Arcy, D.M.; Corrigan, O.I.; Healy, A.M. Evaluation of hydrodynamics in the basket dissolution apparatus using computational fluid dynamics-Dissolution rate implications. Eur. J. Pharm. Sci. 2006, 27, 259-267. [CrossRef]

10. D'Arcy, D.M.; Liu, B.; Bradley, G.; Healy, A.M.; Corrigan, O.I. Hydrodynamic and Species Transfer Simulations in the USP 4 Dissolution Apparatus: Considerations for Dissolution in a Low Velocity Pulsing Flow. Pharm. Res. 2009, 27, 246-258. [CrossRef] 
11. Tharakan, A.; Norton, I.; Fryer, P.; Bakalis, S. Mass Transfer and Nutrient Absorption in a Simulated Model of Small Intestine. J. Food Sci. 2010, 75, E339-E346. [CrossRef]

12. Bai, G.; Armenante, P.M. Hydrodynamic, mass transfer, and dissolution effects induced by tablet location during dissolution testing. J. Pharm. Sci. 2009, 98, 1511-1531. [CrossRef]

13. Bai, G.; Armenante, P.M.; Plank, R.V.; Gentzler, M.; Ford, K.; Harmon, P. Hydrodynamic Investigation of USP Dissolution Test Apparatus II. J. Pharm. Sci. 2007, 96, 2327-2349. [CrossRef] [PubMed]

14. Bai, G.; Armenante, P.M. Velocity Distribution and Shear Rate Variability Resulting from Changes in the Impeller Location in the USP Dissolution Testing Apparatus II. Pharm. Res. 2007, 25, 320-336. [CrossRef] [PubMed]

15. Bai, G.; Wang, Y.; Armenante, P.M. Velocity profiles and shear strain rate variability in the USP Dissolution Testing Apparatus 2 at different impeller agitation speeds. Int. J. Pharm. 2011, 403, 1-14. [CrossRef] [PubMed]

16. Baxter, J.L.; Kukura, J.; Muzzio, F.J. Hydrodynamics-induced variability in the USP apparatus II dissolution test. Int. J. Pharm. 2005, 292, 17-28. [CrossRef]

17. Kukura, J.; Baxter, J.; Muzzio, F. Shear distribution and variability in the USP Apparatus 2 under turbulent conditions. Int. J. Pharm. 2004, 279, 9-17. [CrossRef]

18. Williams, R.O.; Reynolds, T.D.; Cabelka, T.D.; Sykora, M.A.; Mahaguna, V.; Iii, R.W. Investigation of Excipient Type and Level on Drug Release from Controlled Release Tablets Containing HPMC. Pharm. Dev. Technol. 2002, 7, 181-193. [CrossRef]

19. Wang, Y.; Snee, R.D.; Keyvan, G.; Muzzio, F.J. Statistical comparison of dissolution profiles. Drug Dev. Ind. Pharm. 2015, 42, 796-807. [CrossRef]

20. Anand, O.; Yu, L.X.; Conner, D.P.; Davit, B.M. Dissolution Testing for Generic Drugs: An FDA Perspective. AAPS J. 2011, 13, 328-335. [CrossRef]

21. Ranz, W.E.; Marshall, W.R., Jr. Evaporation from drops-Part II. Chem. Eng. Prog. 1952, 48, 173-180.

22. Schutyser, M.A.; Perdana, J.; Boom, R.M. Single droplet drying for optimal spray drying of enzymes and probiotics. Trends Food Sci. Technol. 2012, 27, 73-82. [CrossRef]

23. Langrish, T.; Premarajah, R. Antioxidant capacity of spray-dried plant extracts: Experiments and simulations. Adv. Powder Technol. 2013, 24, 771-779. [CrossRef]

24. Rodriguez-Campos, J.; Escalona-Buendía, H.; Contreras-Ramos, S.M.; Orozco-Avila, I.; Jaramillo-Flores, E.; Lugo-Cervantes, E. Effect of fermentation time and drying temperature on volatile compounds in cocoa. Food Chem. 2012, 132, 277-288. [CrossRef] [PubMed]

25. Li, H.; Dhital, S.; Gidley, M.J.; Gilbert, R.G. A more general approach to fitting digestion kinetics of starch in food. Carbohydr. Polym. 2019, 225, 115244. [CrossRef] [PubMed]

26. Lentle, R.G.; Janssen, P.W.M. Manipulating Digestion with Foods Designed to Change the Physical Characteristics of Digesta. Crit. Rev. Food Sci. Nutr. 2010, 50, 130-145. [CrossRef] [PubMed]

27. Zhong, C.; Langrish, T. A comparison of different physical stomach models and an analysis of shear stresses and strains in these system. Food Res. Int. 2020, 135, 109296. [CrossRef]

28. Maswadeh, H.; Raslan, H. In vitrodissolution kinetic study of theophylline from mixed controlled release matrix tablets containing hydroxypropylmethyl cellulose and glycerylbehenate. Indian J. Pharm. Sci. 2006, 68, 308. [CrossRef]

29. Martin, A.; Newburger, J.; Adjei, A. Extended hildebrand solubility approach: Solubility of theophylline in polar binary solvents. J. Pharm. Sci. 1980, 69, 487-491. [CrossRef]

30. Kestin, J.; Sokolov, M.; Wakeham, W.A. Viscosity of Liquid Water in the Range $-8^{\circ} \mathrm{C}$ to $150{ }^{\circ} \mathrm{C}$. J. Phys. Chem. Ref. Data 1978, 7 , 941-948. [CrossRef] 